\title{
Education for Self-Fulfillment: process and context
}

\author{
Robert A. Stebbins' \\ 'University of Calgary, Calgary, Alberta - Canada
}

\begin{abstract}
Education for Self-Fulfillment: process and context. Education gained through leisure activities plays a central role in our search for self-fulfillment, be the leisure activity a project or a serious pursuit. After discussing the serious leisure perspective, education, both formal and informal, is explored for its special contribution to fostering fulfillment, defined as the realization of personal tastes, talents, and potential. Several key concepts marking the road to fulfillment are discussed: life course, process, leisure education, adult education, self-directed learning, and experience. The ways that acquired education as background knowledge is applied constitute a crucial step in finding self-fulfillment in an activity. The role of Internet and digital technology is also examined.

Keywords: Education. Leisure. Self-Fulfillment. Self-Directed Learning.
\end{abstract}

RESUMO - Educação para a Autorrealização: processo e contexto. A educação obtida através de atividades de lazer desempenha um papel central em nossa busca por autorrealização, seja a atividade de lazer um projeto ou uma ocupação séria. Depois de discutir a perspectiva do lazer sério, a educação formal e informal é explorada por sua contribuição especial para promover a realização, definida como o desenvolvimento de gostos, talentos e potencial pessoais. São discutidos diversos conceitos-chave que marcam a caminhada rumo à realização: trajetória de vida, processo, educação pelo lazer, educação de adultos, aprendizagem autodirigida e experiência. As maneiras como a educação adquirida como saberes prévios é aplicada constitui uma etapa fundamental para encontrar a autorrealização em uma atividade. O papel da internet e da tecnologia digital também é examinado. Palavras-chave: Educação. Lazer. Autorrealização. Aprendizagem Autodirigida.

Educação \& Realidade, Porto Alegre, v. 41, n. 3, p. 873-887, July/Sept. 2016. 873 http://dx.doi.org/10.1590/2175-623651738 


\section{Introduction}

Self-fulfillment is the process of realizing through sustained effort and achievement in an activity one's own potential, one's own talents and tastes. Such realization is most deeply found in what will be described shortly serious leisure and devotee work, or the serious pursuits. Self-fulfillment is also possible in project-based leisure, but there it is significantly more superficial than in the long-term serious pursuits with their attractive careers of involvement.

Education plays a central role in self-fulfillment, be the activity a project or a serious pursuit. The goal of this article is to examine this role in both its formal and informal aspects as it drives the serious pursuits. Space limits prevent an equivalent treatment of the leisure projects, whose importance is evident in Stebbins $(2005 ; 2014 a)$. But, before discussing education in leisure, we must consider the rudiments of the serious leisure perspective (SLP).

\section{Serious Leisure Perspective}

Within the SLP leisure is defined as un-coerced, contextually framed activity engaged in during free time, which people want to do and, using their abilities and resources, actually do in either a satisfying or a fulfilling way (or both) (this, the most recent definition, comes from Stebbins, 2012). More particularly, serious, casual, and project-based leisure constitute the foundation of this Perspective. So far as we know in the interdisciplinary field of leisure studies, these three forms together embrace all leisure activities. The SLP is thus the theoretic framework that synthesizes three main forms of leisure showing, at once, their distinctive features, similarities, and interrelationships. More precisely the serious leisure perspective offers a classification and explanation of all leisure activities and experiences, as these two are framed in the social psychological, social, cultural, geographical and historical conditions in which each activity and accompanying experience take place.

In the spirit of the extensive exploration that underlies the Perspective, its three forms considered together there are not conceived of as encompassing all possible (as opposed to all known) leisure activities, since one or more new forms could be discovered or existing forms substantially refashioned. Over 40 years of research and theoretic work on leisure in the name of the Perspective have led to development of a typological map of the world of leisure, the most recent version of which is available on the SLP website (diagrams at www.seriousleisure.net/). A full discussion of this map as well as the three forms is available in Stebbins (2015) and in Elkington and Stebbins (2014). 


\section{Three Forms}

The serious form comes in two varieties: serious leisure and devotee work. Because of their similarity I will when appropriate refer to them together as the serious pursuits. Serious leisure is the systematic pursuit of an amateur, hobbyist, or volunteer activity. It is sufficiently substantial, interesting, and fulfilling for the participant to find a career there acquiring and expressing a combination of its special skills, knowledge, and experience. This career is experienced in free time, however, during which the individual gets better and better as an amateur, hobbyist, or volunteer. It may be necessary to persevere when, for example, mastery of a skill or idea proves elusive. And because decline is possible in these activities (e.g., athletes who are past their prime), decline may also be part of this kind of career.

Devotee work is activity in which participants feel a powerful devotion, or strong, positive attachment, to an occupation that they are proud to be in (devotee work was first discussed in Stebbins, 2014b, p. 73-75 and now elaborated in Stebbins, 2014a). In such work the sense of career and achievement is high and the core activity endowed with such intense appeal that the line between this work and leisure is virtually erased. Thus one way of understanding this level of appeal is to view devotee work as serious leisure from which a full or partial livelihood is possible. For evidence supporting this proposition, see Walker and Fenton's (2013) study of productive leisure researchers.

I use the term career broadly in this definition of serious pursuit, based on Goffman's (1961, p. 127-128) elaboration of the idea of moral career. Such careers are available in all substantial, complicated roles, including especially those in work, leisure, politics, religion, volunteering, and interpersonal relationships (see also Hewitt, 1991, p. 246; Lindesmith; Strauss; Denzin, 1991, p. 277). The adjective serious (a word Stebbins's research respondents often used) embodies such qualities as earnestness, sincerity, importance, and carefulness. This adjective signals the importance of amateur, hobbyist, and career volunteering activity in the everyday lives of participants, in that pursuing these three eventually engenders deep self-fulfillment.

Casual leisure is immediately intrinsically rewarding, relatively short-lived pleasurable activity requiring little or no special training to enjoy it (Stebbins, 1997). It is fundamentally hedonic, engaged in for the significant level of pure enjoyment, or pleasure, found there. It is also the classificatory home of much of the deviant leisure discussed by Stebbins (1996) and Rojek (1997). Casual leisure is further distinguished from serious leisure by six characteristics of the latter (presented shortly).

Project-based leisure is a short-term, moderately complicated, either one-shot or occasional, though infrequent, creative undertaking carried out in free time (Stebbins, 2005). It requires considerable plan- 
Education for Self-Fulfillment

ning, effort, and sometimes skill or knowledge, but for all that is neither serious leisure nor activity intended to develop into such. Nor is it casual leisure. The adjective occasional describes widely spaced, undertakings for such regular occasions as arts festivals, sports events, religious holidays, individual birthdays, or national holidays. The adjective creative indicates that the undertaking results in something new or different, showing imagination, and possibly routine skill or knowledge. Though most projects would appear to be continuously pursued until completed, it is conceivable that some might be interrupted for several weeks, months, or even years.

\title{
Distinguishing Qualities
}

Serious leisure is further defined and thereby separated from casual and project-based leisure by six distinguishing qualities (Stebbins, 2015). One is the occasional need to persevere. It is clear that some positive feelings about the activity come from sticking with it through thick and thin, conquering adversity. A second quality is finding a leisure (non-work) career in the serious leisure role. Careers in serious leisure commonly rest on a third quality: significant personal effort based on specially acquired knowledge, training, experience, and/or skill. Fourth, several durable benefits, or broad outcomes, of serious leisure have been identified so far, mostly through research on amateurs. They are self-development, self-enrichment, self-expression, regeneration or renewal of self, feelings of accomplishment, enhancement of self-image, social interaction and belongingness, and lasting physical products of the activity (e.g., a painting, scientific paper, a piece of furniture). Self-gratification, the combination of superficial enjoyment and deep fulfilment, is a further benefit and also one of the main benefits of casual leisure; however, enjoyment dominates. Of these benefits, self-fulfilment - realizing or having realized to the fullest one's gifts and character, one's potential - is the most powerful of all. A fifth quality of serious leisure is the unique ethos that develops, a central component of which is a special social world where participants can pursue their freetime interests. Unruh (1980, p. 277) developed the following definition:

\begin{abstract}
A social world must be seen as a unit of social organization which is diffuse and amorphous in character. Generally larger than groups or organizations, social worlds are not necessarily defined by formal boundaries, membership lists, or spatial territory. [...] A social world must be seen as an internally recognizable constellation of actors, organizations, events, and practices which have coalesced into a perceived sphere of interest and involvement for participants. Characteristically, a social world lacks a powerful centralized authority structure and is delimited by [...] effective communication and not territory nor formal group membership.
\end{abstract}


The sixth quality revolves around the preceding five: serious leisure participants tend to identify strongly with their chosen pursuits. In contrast, casual leisure is too fleeting, mundane, and commonplace for most people to find a distinctive identity there.

\section{Education}

For the purposes of this article, education is defined broadly as the process of developing mental or physical powers, if not both, as this process leads to the formation of character or an aspect of it. Education of this sort may be formal; it is given and received in specially designed instructional programs ranging in length from a few hours (e.g., an adult education course on how to canoe) to many years (e.g., a doctoral program in leisure studies). Or the education may be informal; it is given and received outside such programs by way of advice, mentoring, posing questions, on-the-job training, coaching (when not formally conducted as an organizational program), self-directed educational activities (e.g., reading, listening, watching), and the like. Nowadays many people use the Internet as a source of informal education, even while formal courses are also available here.

Education, formal and informal, can lay the foundation for a formative career (Stebbins, 2009, p. 68-69). A formative career is the individual's sense of continuous, positive personal development as it unfolds over that person's lifetime. It is a subjective concept (Stebbins, 1970), a major component of which is the leisure career.

A leisure career is the typical course, or passage, of a type of amateur, hobbyist, or volunteer that carries the person into and through a leisure role and possibly into and through a work role. The effect of human agency in a person's career in a serious pursuit is evident in his or her acquisition and expression of a combination of the special skills, knowledge, and experience associated with the core activities. Furthermore, every serious leisure career both frames and is framed by the continuous search for certain rewards (they are set out in Stebbins, 2015, p. 14), a search that takes months, and in some fields years, before the participant consistently finds deep fulfilment in the chosen amateur, hobbyist, or volunteer role or sometimes later on, in a variety of devotee work. Leisure career, thus considered, is, it should now be clear, a major source of motivation to continue pursuing the activity.

As near as I can tell, for the majority of formative careers, whether based in work, leisure, or both, people in them develop themselves through formal and informal education. Indeed it is difficult to imagine a kind of devotee work or serious leisure the preparation for which could only be formal. Yet there are kinds of work and leisure that some enthusiasts pursue with only informal education, among them, collecting, amateur sport, amateur entertainment, do-it-yourself, and certain small businesses of the devotee variety. 
Education for Self-Fulfillment

\section{Life Course}

Unlike career, linked as it is to particular roles and serious pursuits, life course is much broader, covering numerous roles as they evolve, interweave, and are assumed or abandoned across the lifetime of a person (Bush; Simmons, 1990). Furthermore, life course, when viewed sociologically, centers on age-graded roles and generational effects. Thus it has a historical dimension as well as links to social structure based on the status associated with each role. For instance, Fisher, Day and Collier (1998) observe that old age is uniquely characterized by generativity which includes taking on the responsibility of caring for others as effected through such roles as parent, spouse, friend, and grandparent. When not perceived as personal obligation such care may lead to fulfilment in a leisure role. Of all the age periods composing the life course, the third age, or that period of life between age 50 and 75 (also known as the age of the young-old or active retirement), offers the richest opportunity for finding fulfilment (Laslett, 1994). Brooks (2007) and Wuthnow (2007), by contrast, discuss the still, little-understood odyssey years, or that period after adolescence and before adulthood (roughly ages 18-35) during which people in this category commonly exist in a state of uncertainty with respect to marriage, work, education, family, and quite possibly, even leisure.

Life course is also broader than the related idea of family life cycle, in that the latter is limited to family matters. Additionally, family life cycle, although chronological as career and life course are, is not, however, essentially processual. Process is a continuous series of actions, events, and changes, and in the social sciences, includes the assumption that these actions and the like emerge from, or are influenced by, each other in seamless fashion. Moreover, this influence may have has past (retrospective), present (immediate), and future (prospective) components. Life cycle, on the other hand, deals with historically arrayed, discrete slices of time, often called phases, and within each, events and actions are typically treated of as static. The classic study of leisure and family life cycle is that of Rhona and Robert Rapoport (1975). In short, life course offers a special slant on leisure and social process.

\section{Why Process is Important}

The most obvious answer to this question is that human social life is, in significant part, processual, and a complete scientific explanation of that life must of necessity include this aspect of it. More subtly, however, is the fact that careers and life course, as processes, are important because they constitute strong motivational forces. Agency is not only a main source of personal action, it is also the process by which the individual carries out that action. For instance, both success and failure in a career often motivate people to try to build on the first to achieve

878 Educação \& Realidade, Porto Alegre, v. 41, n. 3, p. 873-887, July/Sept. 2016. 
still more success and do what they can to avoid the second. As Gert and Tedder (2007) put it, agency is also an achieved disposition involving active engagement with the person's contexts-for-action. Thus, concerning their life course, people often seem to want, for example, to harmonize personal interests and role obligations. Thus Wearing and Fullagar (1996) concluded from their studies of Australian women that, today, some of them are modifying traditional family roles to put themselves in a position to pursue activities not traditionally open to females.

Moreover, both career and life course, by dint of their emergent qualities, encourage people to take stock of what has happened up to a certain point in time in a particular career or during one's life. The life review (Butler, 1963), said to be common among the elderly, exemplifies stock-taking of the life course variety. It involves returning to past experiences and unresolved conflicts to make new interpretations of both, the aim being to reintegrate them into life as it has since unfolded. The life review can be conducted by, among other ways, writing memoirs (Stebbins, 2011).

\section{Leisure Education}

The ideas presented above are consistent with Charles Brightbill's definition of leisure education: "[...] the process of helping all persons develop appreciations, interests, skills, and opportunities that will enable them to use their leisure in personally rewarding ways" (Brightbill, 1961, p. 188). Brightbill wrote about education for leisure, when leisure was a growing but still only a small part of life. Our interest - and his definition harmonizes well with it - is broader, however; leisure education is an effective adaptation to the modern era, part of education for personal development in which leisure plays a central role. The foregoing statement on career and life course attests this.

Given the passage just quoted, I think it safe to say that, were Brightbill writing today, he would argue that leisure education should be centered, for the most part, on either the serious pursuits or the leisure projects, if not both. In particular, such education should consist mainly of imparting knowledge about the nature of these two forms, about their costs and rewards, and about how to find and participate in particular leisure activities of this sort. This conception of leisure education intentionally excludes much of casual leisure, on grounds that such leisure, hedonic as it is, requires little or no training or encouragement to engage in it and find enjoyment there.

Since the general public is largely unaware of the concepts of serious and project-based leisure, the first goal of educators for leisure, who when conceived of broadly include counsellors, certain volunteers, and classroom instructors as well as people giving informal advice is to inform their clients or students about the nature and value of these two. Such information is important for anyone searching for an optimal 
leisure lifestyle. More particularly, such education should be composed of instruction on the nature of serious and project-based leisure, the general rewards (and costs) of such activity, the possibility of finding a leisure career in the first, and the variety of social and psychological advantages that can accrue to the person who pursues either of them (e.g., special identity, attractive routine and lifestyle, organizational belonging, central life interest, membership in a social world). Furthermore some people will need advice on how to get started in the pursuits of interest to them.

Elsewhere, I and others provide information on how to do this in North America (Stebbins, 1998; Olson, 2006; Leitner; Leitner, 1994), which however, may sometimes be inappropriate for other parts of the world. Thus, to more effectively guide the people they are working with, leisure educators outside North America may have to gather information on how to get started that is specific to their country and local community. Everywhere culturally sensitive leisure education can help ensure smooth passage into, what for most people, is uncharted territory: the world of fulfilling free time (see Cohen-Gewerc; Stebbins, 2007).

\title{
Adult Education
}

Since I have examined elsewhere in detail the link between adult education and leisure (Stebbins, 2001), we need here only consider, in broad terms, this link. This will set the stage for a longer discussion on lifelong learning and the SLP. As a guide we shall use the definition of adult education prepared by UNESCO (1977, p. 2):

\begin{abstract}
Adult education is the entire body of organized educational processes, whatever the content, level and method, whether formal or otherwise, whether they prolong or replace initial education in schools, colleges and universities as well as apprenticeship, whereby persons regarded as adult by the society to which they belong develop their abilities, enrich their knowledge, improve their technical or professional qualifications or turn them in a new direction and bring about changes in their attitudes or behavior in the twofold perspective of full personal development and participation in balanced and independent social, economic and cultural development.
\end{abstract}

Learning - adult learning in particular - is the object of these educational processes. Continuing education often refers to the same processes, although the idea usually connotes furthering a person's education beyond initial education undertaken as preparation for a work role (Jarvis, 1995, p. 29).

In general, and in harmony with the emphasis in leisure education, adult education centers, for the most part, on the serious pursuits rather than casual leisure. Such education can also be undertaken as 
a leisure project (e.g., a short course on preparing genealogies before attempting to write one's own). In the serious pursuits amateurs in many arts and scientific fields, for example, avail themselves of adult education courses, and in the arts, even whole programs, that further learning of their free-time passion. The same may be said for most of the individual amateur sports (e.g., golf, tennis, racquet ball). Still, if we examine all the adult educational programs available in the typical North American city, it becomes clear that they ignore some amateur activities (e.g., handball, rodeo, weight lifting as well as auto and motorcycle racing and virtually all the entertainment arts, Stebbins, 2001).

Adult education is also, with the exception of collecting, a main avenue for learning hobbies. A great range of making and tinkering activities fill the multitude of North American adult education catalogues, including baking, decorating, do-it-yourself, raising and breeding, and various crafts (for a discussion of the many different hobbies, see Stebbins, 1998, Chapter 3). The same is true for activity participation, which includes such diverse enthusiasms as scuba diving, cross-country skiing, mushroom gathering, and ballroom dancing as well as a few of the hobbyist activities and sports and games (e.g., bridge, orienteering, and the martial arts). On the other hand the liberal arts hobbies are most often acquired purely through self-direction, chiefly by reading. But here, too, we find exceptions, as in the general interest courses offered on certain arts, cultures, philosophies, and histories. Indeed, language instruction is one of the pillars of adult education.

Adult education courses related to volunteerism center mostly in such areas as fund raising, accounting and book-keeping, and management and recruitment of volunteers. To the extent that serious leisure volunteers are involved in these areas, they are likely to be interested in courses bearing on them. Still many career volunteers devote themselves to other tasks, which they learn outside the framework of adult education. That is, the group (club, society, association, organization) in which they serve provides the basic instruction they need to learn further while on the job.

Consonant with Houle's (1961) distinction between learning-oriented and goal-oriented motives for pursuing adult education is the fact that the liberal arts hobbies are the only form of serious leisure where learning is an end in itself. By contrast, amateurs, volunteers, and other hobbyists use educational learning as a means to particular leisure ends, such as producing art, playing sport, collecting objects, or helping others. Sometimes both types of participant enrol in the same course, a pattern that may be especially common in science. Thus, some students in an adult education astronomy course may be liberal arts hobbyists, while others are there to learn about the heavens as background for their research.

Jones and Symon (2001) draw a similar distinction in their exploration of the implications of this difference for governmental policy 
in Britain. They note that adult education and lifelong learning offer resources oriented toward serious learning for six special groups: the unemployed, unwaged (volunteers), elderly, women, portfolio workers (hold many different jobs over a lifetime), and people with disabilities. Serious leisure offers an involving, fulfilling career to these groups that some of their members once had at work and other members never had there. Contemporary governmental policy in Britain (and, I should like to add, quite likely in all other Western countries) tends to overlook the existence of serious leisure and its implications for personal fulfillment, quality of life, and well-being.

Project-based leisure describes what people are doing when they take one or a few courses, with no intention of further involvement in the subject studied. Many a person has sat through an adult educational course on, say, astronomy, music appreciation, or a genre of history simply for the pure satisfaction of learning something interesting in these areas. Having learned what they set out to learn, they see that project as completed, perhaps then moving on to another project.

\section{Self-Directed Learning}

Roberson (2005) notes the crucial differences between adult education and self-directed learning and then links the second to serious leisure. Drawing on an earlier conceptualization by Lambdin (1997), he says that "[...] self-directed learning is intentional and self-planned learning where the individual is clearly in control of this process" (Roberson, 2005, p. 205). Such learning may be formal (here it would be synonymous with adult education), but most often, it is informal. An important condition is agency, that the learner controls the start, direction, and termination of the learning experience. Both adult education and self-directed learning are types of lifelong learning. The latter is a broader idea than the first two, summarized by Selman and colleagues (1998, p. 21) as learning done throughout a person's lifetime, "[...] from the cradle to the grave".

Roberson (2005) found that his sample of rural, elderly Americans (in the State of Georgia) took their learning seriously, as they pursued amateur, hobbyist, or volunteer roles. At the same time the respondents also said they enjoyed or had fun in these learning experiences. Roberson said they were playful when involved in them. In fact his findings would seem to lend empirical weight to the importance of the reward of self-gratification, where participants find a combination of superficial enjoyment and deep self-fulfilment.

\section{Application}

Education, formal or informal, adult or self-directed, gives the background knowledge needed to pursue a formative career. In some 
careers of this sort this knowledge is directly applicable. Thus, the engineer who has learned how to design a bridge, when called upon to do so, applies what she has been taught. The physician, having learned in medical school how to diagnose the common cold, uses this knowledge with patients presenting appropriate symptoms. A hobbyist writer, with a course or two on creative writing under his belt, is now ready to apply what he has learned there in writing a poem or a short story.

Still there are occupational devotees and serious leisure participants (amateurs, hobbyists) who must learn further how to use the knowledge they have acquired. For some of these people this entails developing one or more skills. In other words, for them, application includes practicing, for instance, a golf swing, some musical scales, certain strokes with a calligraphy pen, or the sleight of hand needed for a magician's trick. Others need a special preparatory learning, as opposed to the background learning acquired through formal and informal education. Preparatory learning is exemplified in learning the lines of a role in a play, the course to be run in a marathon, the responsibilities of a volunteer position, or the rules of contract bridge. As with the acquisition of skills such preparation is required in certain kinds of devotee work and serious leisure.

\section{Experience}

One of the strengths of the concept of formative career is that it accords a place for experience in devotee and serious leisure activities. Gaining experience in such activities takes time; that is, it comes through repeated application of skill, education, and preparatory knowledge. My respondents in the several studies of serious leisure and devotee work that I have conducted over the years often talked about the importance of being experienced in what they did. For them greater experience translated into a smoother, less problematic, more efficient pursuit of both the core and the peripheral activities of their work or leisure than was possible with less experience. In other words experience elevated the positiveness of their participation in these two domains.

But what, in detail, does experience consist of? It consists of familiarity with the usual or typical circumstances and situations in which core activities are pursued, leading to an ever more refined judgment of how to pursue those activities (Stebbins, 2014c). Experience, itself, is a kind of knowledge, gained as it were on the job, and as such differs from the background and preparatory types. Some experience is the result of conscious retrospective observation and reflection (e.g., postmortem analyses of a concert, game, speech), whereas other experience is gained subconsciously and expressed in the subtle adjustments seasoned participants automatically make to particular environmental cues. As an example of the latter, I, as a jazz bassist, know from experience when the rhythm section (usually some combination of drums,

Educação \& Realidade, Porto Alegre, v. 41, n. 3, p. 873-887, July/Sept. 2016. 883 
bass, guitar, and piano) is playing together optimally. My past years in this activity, during which the rhythm has sometimes been optimal and sometimes less so, combine today to tell me how well a given musical group is performing rhythmically and where the problem lies when, in this respect, it is performing poorly. Turning to sport the clever moves of seasoned athletes may be traced, in substantial part, to the subtle lessons of past experience.

\section{The Internet and Digital Technology}

The Internet bears on all we have covered so far in this article. For one, it may be a source of formal or informal educational knowledge, as seen in online courses (formal) and online encyclopedias and specialized websites (both are informal). Indeed, the Internet is a tremendous resource for self-directed learning, though users must figure out how to differentiate authoritative from non-authoritative sources. Two, the Internet is more than a repository of knowledge, given that it also enables pursuit of certain serious leisure activities, for example, online scrabble, poker, and a great variety of games known only in the cyberworld (Silverman, 2006, studied serious leisure participants in massive multiplayer online games). Some online serious leisure activities are fraught with moral implications, as in the online hobbyist clubs devoted to revealing the nature of locks and the skills of picking them (Muñoz, 2006) and those that promote and facilitate mate swapping. Three, the Internet offers information (as distinct from education) of practical value in pursuing a career in devotee work or serious leisure. For instance, a professional chemist might go to a website to learn more about a conference he wants to attend. A liberal arts hobbyist might seek books in her area of interest by browsing one or more online book stores.

The digital world is also a source of both formal and informal education. For instance, databases containing entire digitized books and issues of periodicals are available to subscribers, whether organizations and their members or non-organized individuals. Some websites have digital libraries composed of material of interest to subscribers or offered free to the interested public. A wide range of material can now be digitized, including written and printed text; drawings, paintings, and photographs; vocal and instrumental music; plans and blueprints, and videos and films. Using this material might, for example, be required in completing a formal assignment in a university course or it might be needed in the informal educational pursuit of a worker, hobbyist, or career volunteer.

\section{Conclusions}

Pierre Joseph Proudhon, $19^{\text {th }}$ century French politician and journalist, summed it up well. He said that "[...] the chief condition on which, 
life, health and vigor depend on, is action. It is by action that an organism develops its faculties, increases its energy, and attains the fulfillment of its destiny". Proudhon's action is what we have been referring to throughout this article as activity. The serious pursuits - e.g., tennis, stamp collecting, ballet dancing, amateur botany, volunteer museum research - are activities. They can engender rich self-fulfillment, which distinguishes them from casual leisure activities. Furthermore, each general activity (tennis, stamp collecting, etc.) has its own set of unique core activities: distinctive sets of interrelated actions or steps that must be followed to achieve the outcome or product that the participant seeks. As with general activities core activities are pursued in work, leisure, and non-work obligation. Consider some examples in serious leisure: a core activity of alpine skiing is descending snow-covered slopes; in cabinet making it is shaping and finishing wood; and in volunteer fire fighting is putting out blazes and rescuing people from them. In each case the participant takes several interrelated steps to successfully ski downhill, make a cabinet, or rescue someone (Stebbins, 2012).

Here, in activities, general and core, one finds the road to self-fulfillment. Still, a person cannot successfully travel this road without education, without learning how to do those activities. This article shows how this learning takes place, formally, informally.

Received November 19, 2014

Approved July 4, 2015

\section{References}

BRIGHTBILL, Charles. Man and Leisure: A Philosophy of Recreation. Englewood Cliffs: Prentice-Hall, 1961.

BROOKS, David. The Odyssey Years. The New York Times, New York, online edition, 9 Oct. 2007. Available at: <http://www.nytimes.com/2007/10/09/opinion/09brooks.html>. Access date: Oct. 312014.

BUSH, David; SIMMONS, Roberta. Socialization Processes over the Life Course. In: ROSENBERG Morris; TURNER, Ralph (Org.). Social Psychology. Brunswick: Transaction, 1990. P. 133-164.

BUTLER, Robert. The Life Review: an interpretation of reminiscence in the aged. Psychiatry, Washington, v. 26, p. 65-76, 1963.

COHEN-GEWERC, Elie; STEBBINS, Robert (Org.). The Pivotal Role of Leisure Education: finding personal-fulfillment in this century. State College: Venture, 2007.

ELKINGTON, Sam; STEBBINS, Robert. The Serious Leisure Perspective: an introduction. London: Routledge, 2014.

FISHER, Bradley; DAY, Michele; COLLIER, Caroline. Successful Aging: volunteerism and generativity in later life. In: REDBURN, David; MCNAMARA, Robert (Org.). Social Gerontology. Westport: Auburn House, 1998. P. 43-54.

GERT, Biesta; TEDDER, Michael. Agency and Learning in the Lifecourse: towards an ecological perspective. Studies in the Education of Adults, Leicester, v. 39, p. 132-149, 2007.

Educação \& Realidade, Porto Alegre, v. 41, n. 3, p. 873-887, July/Sept. 2016. 
GOFFMAN, Erving. Asylums: essays on the social situation of mental patients and other inmates. Garden City: Doubleday, 1961.

HEWITT, John. Self and Society. Boston: Allyn and Bacon, 1991.

HOULE, Cyril. The Inquiring Mind. Madison: University of Wisconsin Press, 1961.

JARVIS, Peter. Adult and Continuing Education. London: Routledge, 1995.

JONES, Ian; SYMON, Graham. Lifelong Learning as Serious Leisure: Policy, Practice, and Potential. Leisure Studies, Bolton, v. 20, n. 4, p. 269-284, 2001.

LAMBDIN, Lois. Elderlearning. Phoenix: Oryx Press, 1997.

LASLETT, Peter. The Third Age, the Fourth Age and the Future. Aging and Society, v. 14, p. 436-447, 1994

LEITNER, Michael; LEITNER, Sarah. How to Improve Your Life through Leisure. Salt Lake City: Northwest Publishing, 1994

LINDESMITH, Alfred; STRAUSS, Anselm; DENZIN, Norman. Social Psychology. Englewood Cliffs: Prentice-Hall, 1991.

MUÑOZ, Sara. In Clubs and Online, Hobbyists Embrace the Joys of Picking. Wall Street Journal, New York, online edition, Oct. 28, 2006. Available at: <http:// www.wsj.com/articles/SB116200169155406795>. Access date: Oct. 31, 2014.

OLSON, Ernest. Personal Development and Discovery through Leisure. Dubuque: Kendall/Hunt, 2006.

RAPOPORT, Robert; RAPOPORT, Rhona. Leisure and the Family Life Cycle. London: Routledge \& Kegan Paul, 1975.

ROBERSON, Donald. Leisure and Learning: an investigation of older adults and self-directed learning. Leisure/Loisir, Waterloo, v. 24, p. 203-238, 2005.

ROJEK, Chris. Leisure Theory: retrospect and prospect. Loisir et Société/Society and Leisure, Quebec, v. 20, p. 383-400, 1997.

SELMAN, Gordon; COOKE, Michael; SELMAN, Mark; DAMPIER, Paul. The Foundations of Adult Education in Canada. Toronto: Thompson Educational Publishing, 1998.

SILVERMAN, Mark. Beyond Fun in Games: the serious leisure of the power gamer. Master's Degree - Concordia University, Montreal, 2006.

STEBBINS, Robert. Career: The Subjective Approach. The Sociological Quarterly, v. 11, n. 1, p. 32-49, 1970.

STEBBINS, Robert. Tolerable Differences: living with deviance. Toronto: McGraw-Hill Ryerson, 1996.

STEBBINS, Robert. Casual Leisure: a conceptual statement. Leisure Studies, Bolton. v. 16, p. 17-25, 1997.

STEBBINS, Robert. After Work: the search for an optimal leisure lifestyle. Calgary: Detselig, 1998.

STEBBINS, Robert. New Directions in the Theory and Research of Serious Leisure. Lewiston: Edwin Mellen, 2001.

STEBBINS, Robert. Project-Based Leisure: Theoretical Neglect of a Common Use of Free Time. Leisure Studies, Bolton, v. 24, p. 1-11, 2005.

STEBBINS, Robert. Personal Decisions in the Public Square: beyond problem solving into a positive sociology. New Brunswick: Transaction, 2009.

886 Educação \& Realidade, Porto Alegre, v. 41, n. 3, p. 873-887, July/Sept. 2016. 
STEBBINS, Robert. Personal Memoirs, Project-Based Leisure and Therapeutic Recreation for Seniors. Leisure Studies Association Newsletter, Bolton, v. 88, p. 29-31, 2011

STEBBINS, Robert. The Idea of Leisure: first principles. New Brunswick: Transaction, 2012.

STEBBINS, Robert. Careers in Serious Leisure: from dabbler to devotee in search of fulfillment. Houndmills: Palgrave Macmillan, 2014a.

STEBBINS, Robert. Between Work and Leisure: the common ground of two separate worlds. New Brunswick: Transaction, 2014b.

STEBBINS, Robert. Experience as Knowledge: its place in leisure. Leisure Studies Association Newsletter, Bolton, v. 98, p. 33-35, 2014c.

STEBBINS, Robert. Serious Leisure: a perspective for our time. New Brunswick: Transaction, 2015.

UNESCO. Recommendation on the Development of Adult Education. In: UNESCO. Records of the General Conference: nineteenth session. Paris: Unesco, 1977. Anexo 1. P. 3-15.

UNRUH, David. The Nature of Social Worlds. Pacific Sociological Review, Thousand Oaks, v. 23, p. 271-296, 1980.

WALKER, Gordon; FENTON, Lara. Backgrounds of, and Factors Affecting, Highly Productive Leisure Researchers. Journal of Leisure Research, v. 45, n. 4, p. 37-62, 2013

WEARING, Betsy; FULLAGER, Simone. The Ambiguity in Australian Women's Family Leisure: some figures and refiguring. In: SAMUEL, Nicole (Org.). Women, Leisure and the Family in Contemporary Society: a multinational perspective. Wallingford: CABI, 1996. P. 15-34.

WUTHNOW, Robert. After the Baby Boomers: how the twenty- and thirty-somethings are shaping the future of american religion. Princeton: Princeton University Press, 2007.

Robert A. Stebbins has a master's degree and a PhD in Sociology from University of Minnesota. He has taught in the departments of sociology at Presbyterian College (1964-65), Memorial University of Newfoundland (1965-73), the University of Texas at Arlington (1973-76), and the University of Calgary (1976 to the present). He is now appointed as Faculty Professor in the Faculty of Social Sciences.

E-mail: stebbins@ucalgary.ca 